\title{
ADELA CROOKE EN DOS VERSIONES: DE LA PINTURA A LA FOTOGRAFIA Y VICEVERSA
}

\author{
Antonia Salvador Benítez ${ }^{1}$ \\ Universidad Complutense de Madrid \\ JuAn Miguel SÁNChez VigIL ${ }^{2}$ \\ Universidad Complutense de Madrid
}

\begin{abstract}
Es objeto de este artículo analizar y difundir las obras pictóricas y fotográficas de la intelectual y coleccionista Adela Crooke y Guzmán, XXIV condesa de Valencia de Don Juan, fundadora del Instituto ${ }^{3}$ de ese nombre junto a su esposo, el diplomático Guillermo de Osma. El estudio se centra, por su especial interés, en el uso que Crooke hizo de sus fotografias para elaborar dibujos y acuarelas, poniendo de manifiesto su valor documental y creativo en el periodo coincidente con el esplendor impresionista. Las obras forman parte de los originales conservados en el Instituto, fechados entre los años 1880 y 1910 , y compuestos por cerca de trescientos dibujos, un centenar de acuarelas y unas cuatro mil fotografías, lo que nos indica su ingente producción y su interés por el arte.

Palabras clave: Adela Crooke; Instituto de Valencia de Don Juan; pintura; fotografía; acuarela; dibujo; relación pintura-fotografía.
\end{abstract}

ADELA CROOKE IN TWO VERSIONS: FROM PAINTING TO PHOTOGRAPHY, AND VICE-VERSA

The goal of this article is to analyze and promote the pictorial and photographic work of art collector and scholar Adela Crooke y Guzmán, the $24^{\text {th }}$ Countess of Valencia de Don Juan, founder of the Institute of the same name, together with her husband, diplomat Guillermo de Osma. The study focuses, due to their exceptional interest, on how Crooke used her photographs to prepare her drawings and watercolors, a circumstance which enhances their documentary and creative value during the height of the Impressionist period. These works form a part of the collection of originals kept in the Institute, made up of close to three hundred originals, a hundred watercolors and four thousand photographs, dated between 1880 and 1910, that tell us a great deal about her extensive production and her great interest in art.

Key words: Adela Crooke; Instituto de Valencia de Don Juan; painting; photography; watercolors; drawing; the painting-photography relationship.

Cómo citar este artículo / Citation: Salvador Benitez, Antonia / Sánchez Vigil, Juan Miguel (2020) “Adela Crooke en dos versiones: de la pintura a la fotografia y viceversa”. En: Archivo Español de Arte, vol. 93, núm. 372, Madrid, pp. 391-408. https://doi.org/10.3989/aearte.2020.26

\section{Introducción}

La relación entre pintura y fotografía fue objeto de debate desde la presentación oficial de esta por Daguerre en la Academia de Ciencias de París en 1839. La discusión sobre su concepción

\footnotetext{
1 asalvado@ucm.es / ORCID iD: https://orcid.org/0000-0003-0087-5707

2 jmvigil@ucm.es / ORCID iD: https://orcid.org/0000-0002-1640-9295

3 Los autores agradecen la colaboración de los responsables del Instituto de Valencia de Don Juan para la realización del artículo.
} 
artística se prolongó hasta finales del siglo XIX, negada como ya es sabido por escritores como Charles Baudelaire, que la calificó de "industria que contribuye no poco a confirmar a la estupidez en su fe y a arruinar lo que habría podido quedar intacto del genio francés"4. Los pintores impresionistas hicieron trizas el conservadurismo al reconocer el uso y aplicación de la fotografía en la documentación y creación de paisajes, escenas y retratos ${ }^{5}$.

El objeto de este trabajo es analizar y difundir la obra pictórica y fotográfica de Adela Crooke, XXIV condesa de Don Juan, cuyo conjunto configura su personal universo de imágenes, y que viene a recuperar nuevos datos para la historia de la pintura y de la fotografía, así como para la aportación de la mujer a las mismas en los últimos años del siglo XIX y los albores del XX. Es significativo que hasta la fecha no se haya escrito en profundidad sobre su obra pictórica, teniendo en cuenta que su producción de dibujos, acuarelas y fotografías, conservadas en el Instituto de Valencia de Don Juan (en adelante IVDJ), es ciertamente elevada y de calidad reconocida en las publicaciones de época ${ }^{6}$.

El análisis de la obra de Crooke se enmarca en tres aspectos generales: los estudios sobre mujeres artistas, el uso y aplicación de la fotografía por la burguesía (círculos amateurs) y la relación entre pintura y fotografía. Cada uno de ellos tiene su propia vía de investigación con referencias bibliográficas específicas. El estado de la cuestión sobre los trabajos de mujeres artistas, en general, nos lleva a varios títulos editados por la Cambridge University Press y a los de otros autores, entre los que citaremos los de Cherry ${ }^{7}$ y Nochlin, Bolloch y Allen ${ }^{8}$. Sobre la actividad fotográfica de las mujeres se ha realizado en España un estudio reciente: Fotografía [Femenino plural] Visiones, ensayos y otros escritos sobre mujeres fotógrafas ${ }^{9}$, con antecedente en trabajos pioneros de Marie Loup Sougez, Mónica Carabias, Maite Jiménez o Antonia Salvador ${ }^{10}$.

Sobre el uso de la fotografía por la burguesía, y partiendo de los clásicos de Freund ${ }^{11}$, son de gran interés, entre otras, las obras de Rouillé, Lemagny o Brunet ${ }^{12}$. En cuanto a la relación entre pintura y fotografía en el último tercio del siglo XIX hemos consultado fundamentalmente dos obras, el clásico Arte y fotografía de Scharf ${ }^{13}$ y la reciente publicación Los impresionistas y la fotografía de Alarcó ${ }^{14}$. A estas, se añaden otras varias de relevancia, entre ellas las de Roger ${ }^{15}$, Ribemont, Daum y Prodger ${ }^{16}$, Jacobi y Kingsley ${ }^{17}$, o el estudio de Zelich en el caso español ${ }^{18}$.

Para el análisis global de las fotografías del IVDJ han sido de gran utilidad los inventarios elaborados por Lázaro y Santos ${ }^{19}$, y como fuente para la referencia biográfica de Crooke se han seguido los textos de Nebreda ${ }^{20}$ y Partearroyo ${ }^{21}$, completados con la investigación propia realizada en la hemeroteca digital de la Biblioteca Nacional de España para obtener más datos en relación a la obra pictórica. Se ha consultado además La Ilustración Española y Americana, y

4 Scharf, 1994: 153.

5 Alarcó, 2019.

${ }^{6}$ La Ilustración Española y Americana, 30 de marzo de 1882, 20 y 23 de febrero de 1883, 12 de mayo de 1883, 30 de junio de 1885, y 8 de septiembre de 1886 .

7 Deborah Cherry, 2000.

8 Nochlin, Bolloch y Allen, 1997.

9 García Ramos; Felten, 2019.

${ }_{10}$ Sougez, Marie Loup, 1997; Carabias Álvaro, Mónica, 2013, 2002a, 2002b, 2000; Salvador Benítez, Antonia, 2009; Jiménez Ochoa de Alda, Maite, 2010.

11 Freund, 1936 y 1976.

12 Rouillé, 1982 y 2017; Lemagny, 1992; Brunet, 2000.

13 Scharf, 1994.

14 Alarcó, 2019.

15 Roger, 1991.

16 Ribemont, Daum y Prodger, 2006.

17 Jacobi y Kingsley, 2016.

18 Zelich. 1998.

19 Lázaro, 2003, 2002; Santos Quer, 2009, 2004.

${ }^{20}$ Nebreda, 2019, 2018.

21 Partearroyo, 2013, 2010. 
por lo que respecta a las fotografías ha sido imprescindible el libro Adela Crooke. Pasión por la fotografia 22 .

La metodología sigue el siguiente esquema: contextualización de la vida y obra del personaje, recopilación de datos a partir de las fuentes (originales pictóricos y fotográficos, bibliografía y hemerografía), valoración cualitativa y cuantitativa de la obra para dar a conocer por primera vez el número de originales pictóricos, y análisis general y particular de los contenidos. Las obras específicas analizadas son todas aquellas de las que se ha localizado el original fotográfico. Por último, se han redactado las conclusiones finales.

\section{Adela Crooke. Apunte biográfico}

Adelaida Crooke y Guzmán (Madrid, 1863-París, 1918), hija de Juan Bautista Crooke y Adelaida Guzmán, condes de Valencia de Don Juan, tuvo cuatro hermanos que fallecieron en la infancia. Desde niña vivió entre las obras de arte que coleccionaban sus progenitores, lo que influiría en su formación. Estudió francés y aprendió pintura y fotografía, y fue viajera empedernida. En 1888 contrajo matrimonio con el diplomático y político Guillermo de Osma y Scull (La Habana, 1853-La Negresse, Francia, 1922), formado en París y Oxford. Ambos compartirían la afición por el coleccionismo de arte, asesorados por intelectuales de prestigio como Manuel Gómez-Moreno, Antonio Vives Escudero, Elías Tormo, José Ramón Mélida, Miguel Asín Palacios o Hugo Obermaier.

Los primeros estudios e investigaciones de Adela Crooke se centraron en la orfebrería, y durante más de una década la imagen fue su pasión a través de dibujo, la acuarela y la fotografía. En 1904, al fallecer su padre, heredó el patrimonio y el título de condesa, y en 1905 donó al Museo Arqueológico Nacional seiscientas cincuenta obras para la exposición de la que fue comisaria en colaboración con el arabista Antonio Vives Escudero ${ }^{23}$.

A comienzos de la segunda década del siglo XX, antes de que se iniciara la Primera Guerra Mundial, se trasladó a París y fijó allí su residencia. Lara Nebreda ${ }^{24}$ señala que esta decisión pudo deberse a dos motivos: "el difícil carácter de su marido o la búsqueda del ambiente idealizado de la Belle Époque que encarnaba la capital de la cultura, la literatura y el arte". En 1916, en plena contienda europea, el matrimonio Osma-Crooke creó el Instituto de Valencia de Don Juan para la exposición e investigación sobre sus colecciones, si bien el germen fue muy anterior como se indica en el documento de 1905 titulado Apuntes para la Memoria explicativa del Proyecto de Museo Instituto ${ }^{25}$.

El administrador de las propiedades de Adela Crooke durante su estancia en París fue Javier García de Leaniz, quien en carta fechada el 18 de enero de 1917 manifestó la opinión de Osma en favor de los aliados: "Debo darle (refiriéndose a las cosas de la guerra y a la nota de contestación que hemos dado a los alemanuchos) una satisfacción confidencial. Don Guillermo fue consultado sobre ella durante toda una mañana que pasó el cojo [conde de Romanones] en Fortuny, y me consta que su juicio fue muy tenido en cuenta. Realmente es seria y digna, pero yo la

22 Sánchez Vigil, Editor, 2019.

23 La exposición del Museo Arqueológico Nacional fue un éxito personal de Adela Crooke y le valió el agradecimiento público de Alfonso XIII, recogido en la Gaceta el 27 de mayo de 1905. La prensa de la época publicó artículos sobre el evento, que coincidían en el reconocimiento a la labor coleccionista de Juan Bautista Crooke, y aún más en la alabanza a la generosidad y el buen gusto de su hija: "El Museo Arqueológico se ha enriquecido con dos nuevas salas, que ha llenado con objetos preciosos de su propiedad la señora condesa de Valencia de Don Juan, que generosamente se los ha cedido al Estado. [...] Cuando tantas riquezas artísticas desaparecen de España; cuando la ignorancia y la codicia nos despojan, es menester ensalzar como se merece el rasgo de patriotismo y de desprendimiento de doña Adela Crooke de Osma, que enriquece un Museo Nacional y rinde homenaje a la memoria de su ilustre padre" ( $E l$ Imparcial, 27 de abril de 1905).

24 Nebreda, 2019; 49.

25 Archivo del Instituto de Valencia de Don Juan. Escritura de Fundación. 
hubiera preferido más francamente inclinada hacia el lado aliado o sea hacia el de la razón y la justicia”.

Adela Crooke se implicó activamente en la contienda y formó parte, como secretaria, de la organización Le Paquetage du Convalescent. Ouvre d'assistance aux soldats français et allies, fundada por la baronesa Michel Peter el 1 de noviembre de 1914 con el objetivo de atender a los soldados heridos en combate. Por su dedicación y entrega fue galardonada por la Brigada de Fusileros de la Marina Francesa, y en la documentación del Instituto de Valencia de Don Juan se conserva un conjunto de tarjetas postales en el que los soldados muestran su agradecimiento.

En los últimos años de su vida tuvo problemas de salud (neuralgias y una operación en los ojos). Murió el 17 de enero de 1918 en París y fue sepultada en el cementerio de Saint-Germain-en-Laye, cerca de la capital. Donó la mayor parte de sus posesiones al Instituto de Valencia de Don Juan, y algunas piezas a distintos centros, entre ellos: Museo Británico, Metropolitan de Nueva York, Cerámica de Sèvres, Bellas Artes de Bruselas y Artes Decorativas Pavillon de Marsan (París).

\section{El universo de la imagen}

Adela Crooke configuró un mundo personal a través de las imágenes que plasmó en sus dibujos, acuarelas y fotografías. Pensar y vivir en la imagen fue habitual durante gran parte de su vida, no solo por sus creaciones sino por los objetos artísticos de su colección, representados en la documentación gráfica que se conserva en el IVDJ. La fotografía fue base, fundamento, además de elemento creativo, para documentar las obras de arte que ella y su marido, Guillermo de Osma, fueron adquiriendo para su particular museo, partiendo de un criterio selectivo directamente relacionado con sus gustos personales.

Este universo tiene, por tanto, paradigma en el imaginario de su colección de arte, de las piezas representadas y de los retratos de personajes anónimos, y sobre todo en las fotografías en las que aparece pintando o captando escenas con la cámara, documentos que ella misma positivó y montó en sus álbumes personales, aplicando un método expositivo, una narrativa basada en los viajes, pero que trasciende la simple memoria para evidenciar sus intereses vitales, sus pasiones y experiencias. Imágenes que definen su manera de ser.

Por otra parte, conoce el impacto de los iconos y las posibilidades de proyección del sujeto o el objeto. Posa en los escenarios escogidos en actitudes que dejan constancia de la personalidad. Aunque los códigos visuales relacionados con el retrato y la representación de la mujer ya estaban codificados en la época ${ }^{26}$, en sus álbumes personales encontramos los referentes desde los que concluir sobre su carácter. Así, la selección de escenarios refleja sus deseos, sus intenciones, el espacio o la temática a mostrar.

Es evidente que elige en cada momento el contexto en el que desea moverse para mostrar los valores de la época, la representación de lo femenino, el ámbito o la esfera social, incluso su identificación con la tradición cultural, siempre con un papel activo y moderno. Todo ello se visibiliza en una categoría donde el escenario se aleja de los códigos trazados para la mujer, como las fotos en la que aparece practicando tiro con pistola en la localidad suiza de Schinznach (1890), paseando en la playa de Biarritz (1889) o posando para Julian Rusell Story ${ }^{27}$ (1889), imagen donde aparecen la modelo, el pintor y su obra [fig. 1].

${ }^{26}$ Onfray, 2018: 13.

27 Julian Russell Story (Walton-on-Thames, Inglaterra 1857-Filadelfia, 1919) era hijo del escultor y poeta William Wetmore Story. y hermano del escultor Thomas Waldo Story. Se educó en los colleges de Eton y Brasenose, de la Universidad de Oxford. Creció en Roma, rodeado de la élite literaria y artística que admiraba a su padre. Se graduó en 1879, comenzando sus estudios de arte con los pintores academicistas Gustave Boulanger y Jules Lefebvre y el estadounidense Frank Duveneck. En 1881 Story realizó el retrato del poeta Robert Browning, y los reconocimientos llegarían a finales de la década de los ochenta con mención en un Salón de París y Medalla de Oro en Berlín. En 1891 se casó con la soprano estadounidense Emma Eames a la que había pintado un retrato. Por su estudio pasaron grandes personalidades, entre ellos Enrique VII. Estableció residencia en Filadelfia y en 1907 se divorció. Su segunda esposa 

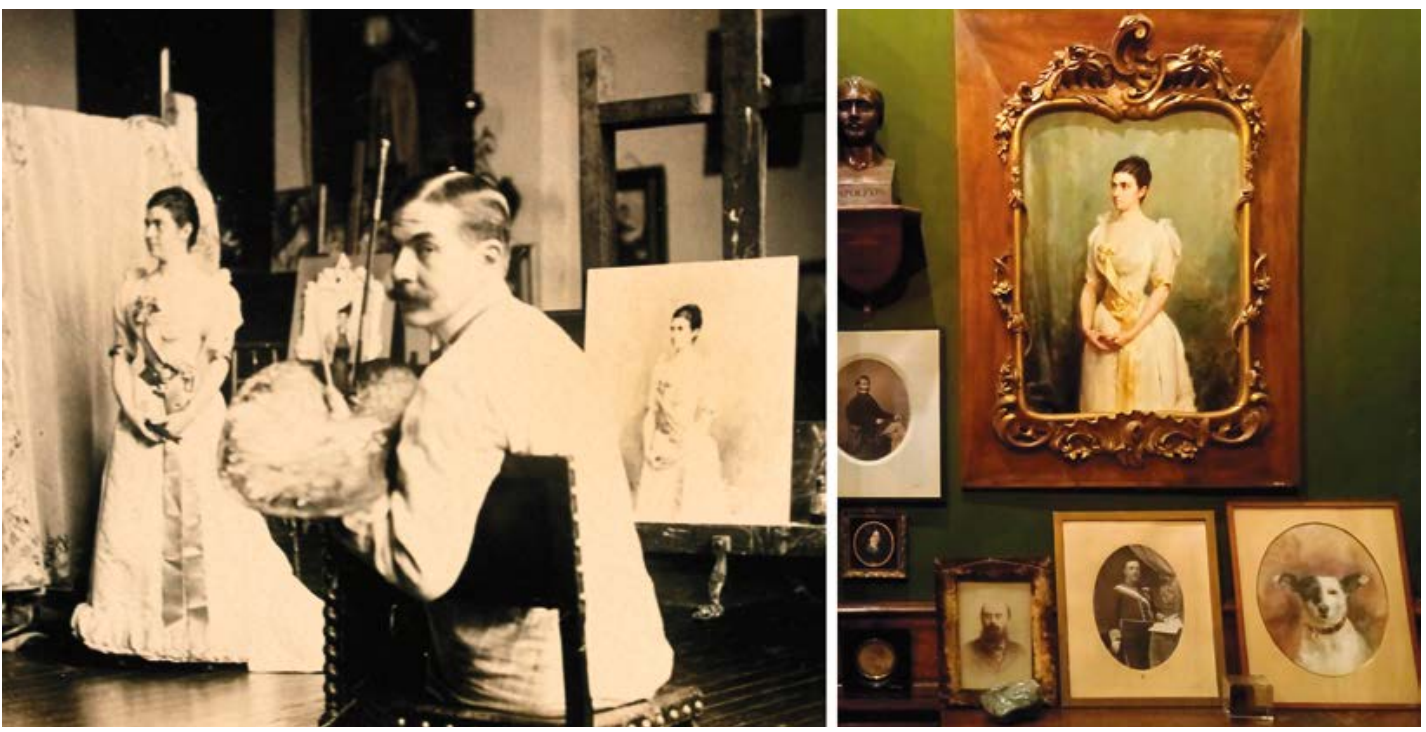

Fig. 1. Adela Crooke posando para Julian Rusell Story, 1889.

A la derecha el óleo, expuesto en el despacho de Guillermo de Osma en el IVDJ.

\section{Obra pictórica: acuarelas y dibujos}

Adela Crooke comenzó su formación pictórica hacia 1880 en el taller de Alfredo Perea Rojas (Madrid, 1839-1895), maestro de la acuarela y reputado ilustrador de prensa que estudió en la Real Academia de Bellas Artes de San Fernando y en París. En 1860 Perea participó en la Exposición Nacional de Bellas Artes con la pintura histórica Felipe II implorando el auxilio de la Divina Majestad, y a partir de 1868 alcanzó gran popularidad por su colaboración en las revistas ilustradas, entre ellas El Museo Universal, Gil Blas, La Ilustración Española y Americana, La Ilustración de Madrid y Gran Vía. Colaboró en numerosos libros, entre ellos Historia del Escorial, de Antonio Rotondo, Galería universal de biografias y retratos, y el Gran Diccionario Taurómaco.

Crooke practicó la acuarela y el dibujo en las dos últimas décadas del siglo XIX, y llegó a exponer junto a Madrazo, Pradilla, Sala o Lhardy, como veremos. Las primeras referencias sobre su actividad se documentan en 1881 gracias a los originales conservados en el IVDJ. En la prensa, los primeros datos aparecen a partir de marzo de 1882 cuando José Fernández Bremon, cronista de arte de La Ilustración Española y Americana, reseñó las obras presentadas a la Exposición del Círculo de Bellas Artes de Madrid. Su trabajo fue un bodegón compuesto por varios objetos, similar al que mostramos [fig. 2], que tomó como modelo de las obras que su padre, Juan Crooke, conde de Valencia de Don Juan, había adquirido para su colección: "Fijémonos después en la obra de una artista, una verdadera artista: la Srta. $\mathrm{D}^{\mathrm{a}}$ Adela Crooke y Guzmán, discípula de Alfredo Perea. Su pequeña acuarela, titulada Un estudio, es una agrupación bien sentida y mejor ejecutada de artísticos objetos: un jarrón árabe, un casco de guerrero del siglo $\mathrm{XV}$, un tapiz de terciopelo con heráldicos blasones, una preciosa rodela morisca. Dibujo, color, luz, armonía; todo esto reúne la acuarela de la Srta. Crooke"28.

En la Exposición del Círculo participaron numerosos autores de prestigio a los que alude Fernández Bremon, entre ellos Madrazo, Rico, Plasencia, Ferrant, Pérez del Camino y cuatro mujeres: la infanta Paz de Borbón (Antes de los toros, acuarela), Fernanda Francés (Plato de Manises), Clara Lengo (Un plato pintado y Una cabeza) y Luisa de la Riva (Flores y frutas).

fue Elaine Sartori Bohlen. El Gobierno francés le nombró Caballero de la Legión de Honor en 1900 (New York Tribune, 25 de febrero de 1919, p. 6).

28 Fernández Bremon, 1882, p. 27. 


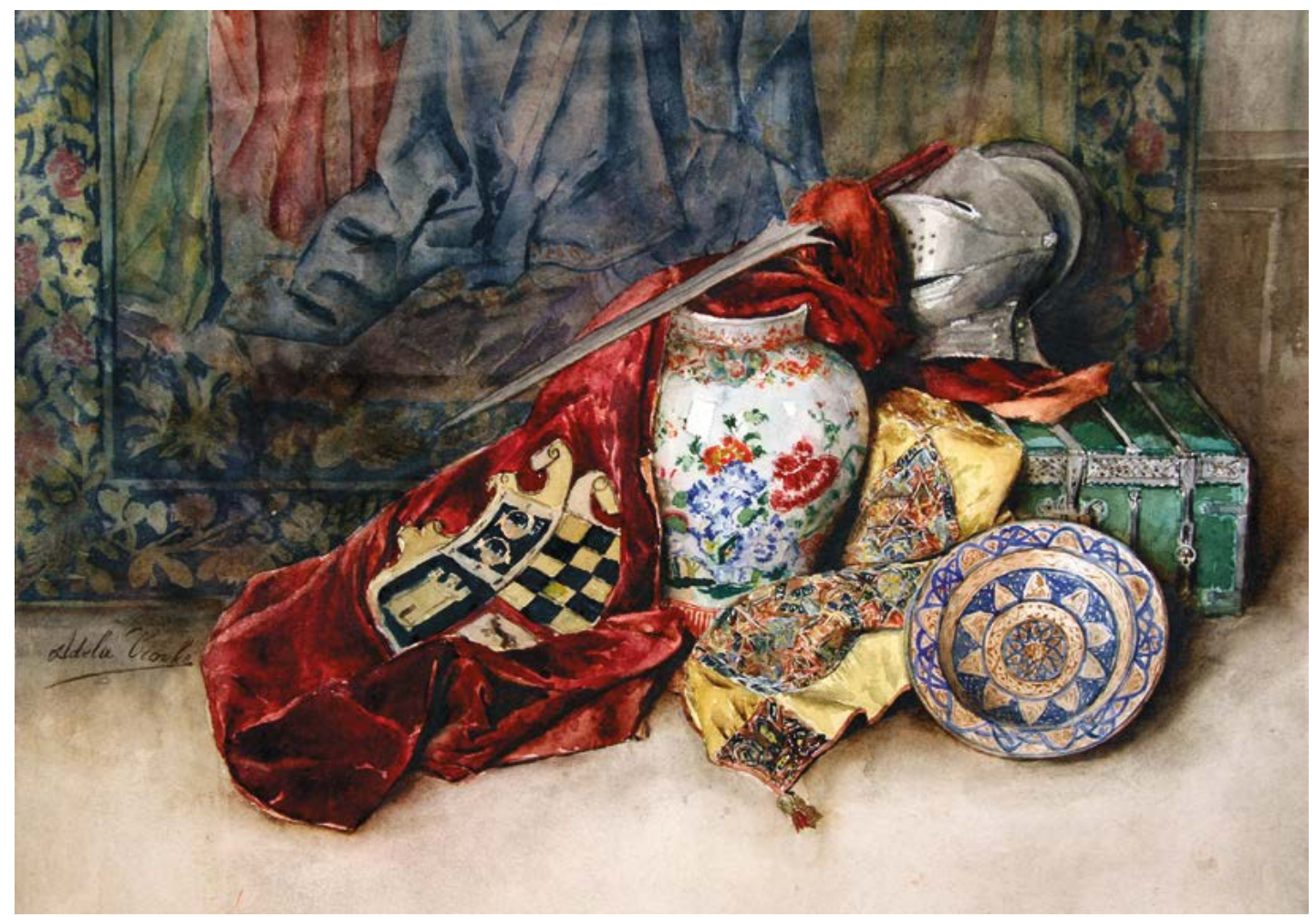

Fig. 2. Adela Crooke. Bodegón con objetos artísticos del Instituto de Valencia de Don Juan, h. 1882.

En febrero de 1883 participó en la "Exposición Hernández" con la obra Estudio del natural, de la que escribió el cronista de La Iberia: "Nos hallamos ahora ante una graciosa niña reclinada en un sillón, en postura muy natural, que el pintor ha elegido con acierto y copiado con fidelidad; el claro-oscuro está bien estudiado, el color es de buena ley. ¿Quién es el autor de tan estimable trabajo? No un pintor avezado a los ejercicios del arte, no un hombre diestro ya por la práctica en el uso de la paleta; es una mujer, casi una niña, Adela Crooke, hija de los condes de Valencia de Don Juan”29. La muestra fue visitada por los monarcas y el príncipe de Baviera, y se expusieron 234 obras de autores como Emilio Sala, Francisco Pradilla, Daniel Hernández y Agustín Lhardy, más otra veintena de reputados pintores y escultores, entre ellos dieciséis mujeres: la infanta Paz (María y En mayo, acuarelas), la señorita (sic) Álvarez de Toledo (Coquetería, óleo), Aurora Arias (dos conchas decoradas), María Azpiraz (pandereta decorada), Adelaida Corera (plato decorado), Manolita Corera (Espejo con flores), Luisa Gámez (Espejo decorado), Adela Ginés (Espejo con flores), Pepita Grande (Pandereta), Luisa Miranda (Paisajes), Virginia Montesinos (abanicos y pandereta pintados), Emilia Menassade (Dos platos decorados), Juana Muñiz (abanico pintado), Luisa de la Riva (abanico pintado), señora de Weil (abanico pintado) y la condesa de Velarde (dibujo a pluma). La mayoría de ellas no eran artistas sino damas de la aristocracia y la burguesía.

En mayo de 1883 colaboró de nuevo con un estudio en la octava muestra organizada por la Sociedad de Acuarelistas de Madrid ( $\mathrm{n}^{\circ} 2$ de la calle Misericordia) que, como anécdota, podía ser visitada por las noches ${ }^{30}$. Se exhibieron 68 obras, algunas de autores de prestigio como Pradilla, Salinas, Hispaleto y Villodas, y fueron cuatro las mujeres participantes: Josefa Serrano, Inés Álvarez, Emilia Menassade y Adela Crooke.

29 “Exposición Hernández", La Época, 23 de febrero 1883.

${ }^{30}$ El Día, 12 de mayo de 1883. Las acuarelas de mayor precio fueron las de Pradilla (4.000 ptas.), Salinas (2.000), Villodas (1.500) e Hispaleto (1.000). 


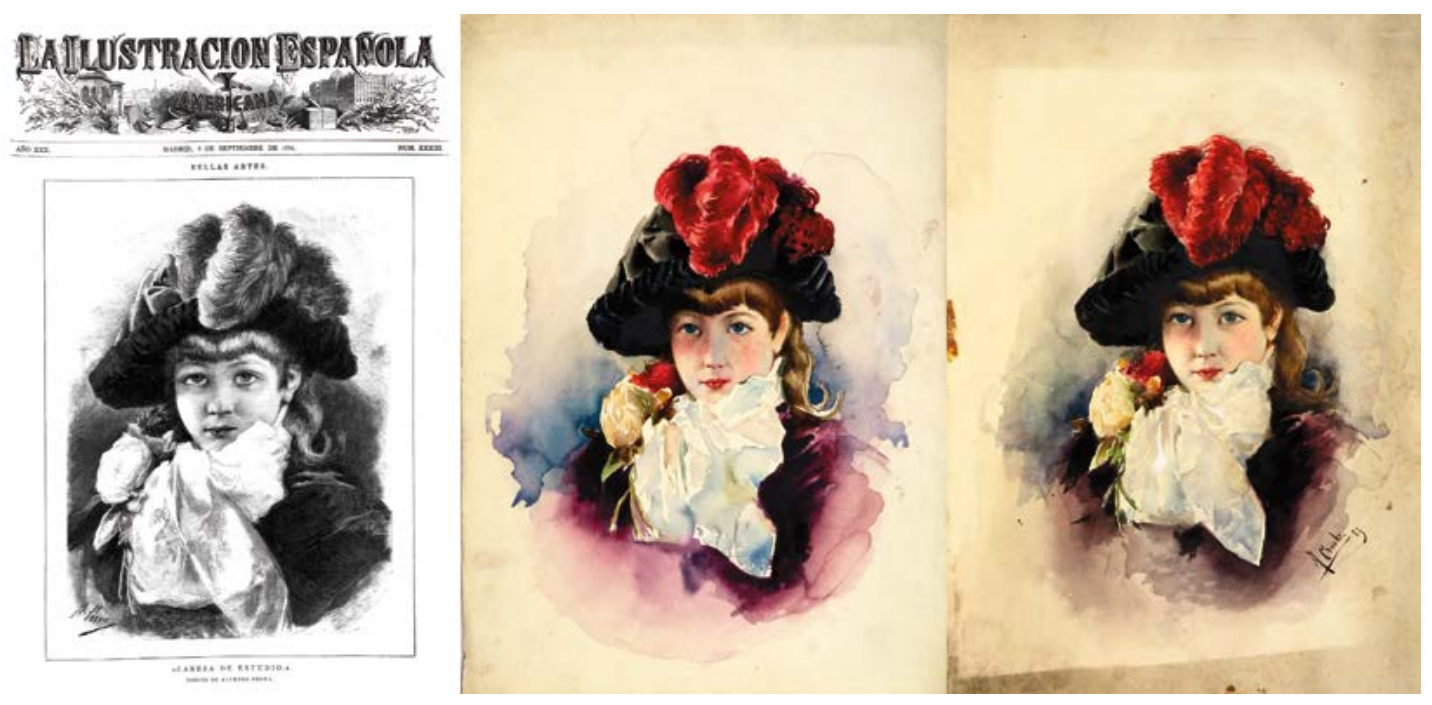

Fig. 3. Dibujo de Alfredo Perea a partir de dos retratos a la acuarela de Adela Crooke. La Ilustración Española y Americana, 8 de septiembre de 1886.

Como puede observarse, es significativa la presencia de mujeres en estos tres eventos, en su mayoría aficionadas como la infanta $\mathrm{Paz}^{31}$ o Inés Álvarez de Toledo ${ }^{32}$, si bien algunas eran profesionales de prestigio, con presencia en los certámenes nacionales e internacionales: Fernanda Francés $^{33}$, Clara Lengo ${ }^{34}$, María Luisa de la Riva ${ }^{35}$ y Emilia Menassade ${ }^{36}$.

El 30 de junio de 1885 La Ilustración Española y Americana reprodujo en portada un dibujo de Crooke realizado a partir de una fotografía de Laurent. Representaba a una joven "de viva mirada y halagüeña sonrisa, en actitud graciosa y al par sencilla". Se advertía en la nota de prensa que era discípula aventajada de Alfredo Perea, y que la obra debía ser considerada "feliz augurio y testimonio indudable de aptitudes ventajosísimas". La relación artística de Perea con Adela Crooke queda de manifiesto al elaborar el pintor un dibujo a partir de una acuarela de su discípula, que fue publicado en portada de La Ilustración Española y Americana el 8 de septiembre de 1886, y de la que se conserva en el Instituto de Valencia de Don Juan el original en dos versiones, una de ellas firmada [fig. 3].

${ }^{31}$ La infanta María de la Paz Borbón (Madrid, 1862-Munich, 1946) vivió su infancia fuera de España y regresó tras la Restauración borbónica en 1875. Entre sus actividades culturales de juventud, antes de casarse con el príncipe Luis de Baviera en 1883, practicó la pintura. Su colaboración en los certámenes nacionales fue habitual a comienzos de la década de los ochenta, donando obras con las que obtener fondos para los necesitados.

32 Inés Álvarez de Toledo y Caro (Madrid, 1857-San Sebastián, 1937), condesa de Bornos y marquesa de Cazaza. Su actividad pictórica fue puntual durante su juventud, antes de casarse en 1884 con Fernando Ramírez de Haro y Patiño.

${ }^{33}$ Fernanda Francés (Valencia, 1862-Madrid, 1939), hija del pintor Plácido Francés, fue catedrática de Pintura en la Escuela de Artes y Oficios (1888) y en la Escuela del Hogar de Madrid. Participó en varias Exposiciones Nacionales de Bellas Artes, con galardones en 1887, 1890, 1897 y 1912.

${ }^{34}$ Clara Lengo Gargallo (Málaga, 1866-Roma, 1938), hija del pintor Horacio Lengo, estudió pintura en el taller de su padre y en París. Participó en varias exposiciones nacionales desde 1882, y vivió en El Espinar (Madrid), Alhama de Murcia y Roma, donde falleció.

${ }^{35}$ María Luisa de la Riva y Callol-Muñoz (Zaragoza, 1859-Madrid, 1926) fue una de las pintoras españolas con mayor proyección internacional. Se casó con el pintor Domingo Muñoz Cuesta y vivió en París. Perteneció a la Unión de Mujeres Pintoras y Escultoras de Francia y Viena, y fue miembro del Jurado de la Sociedad de Mujeres Artistas de París. Expuso en numerosas muestras nacionales de Bellas Artes y recibió varios premios nacionales e internacionales.

${ }_{36}$ Emilia Menassade Baluze (París, 1850-Madrid, 1897) residió en San Sebastián y participó en varias Exposiciones Nacionales de Bellas Artes, con galardones en 1887 y 1892. En 1897 publicó el libro de viajes A travers le Guipuzcoa: impressions. 


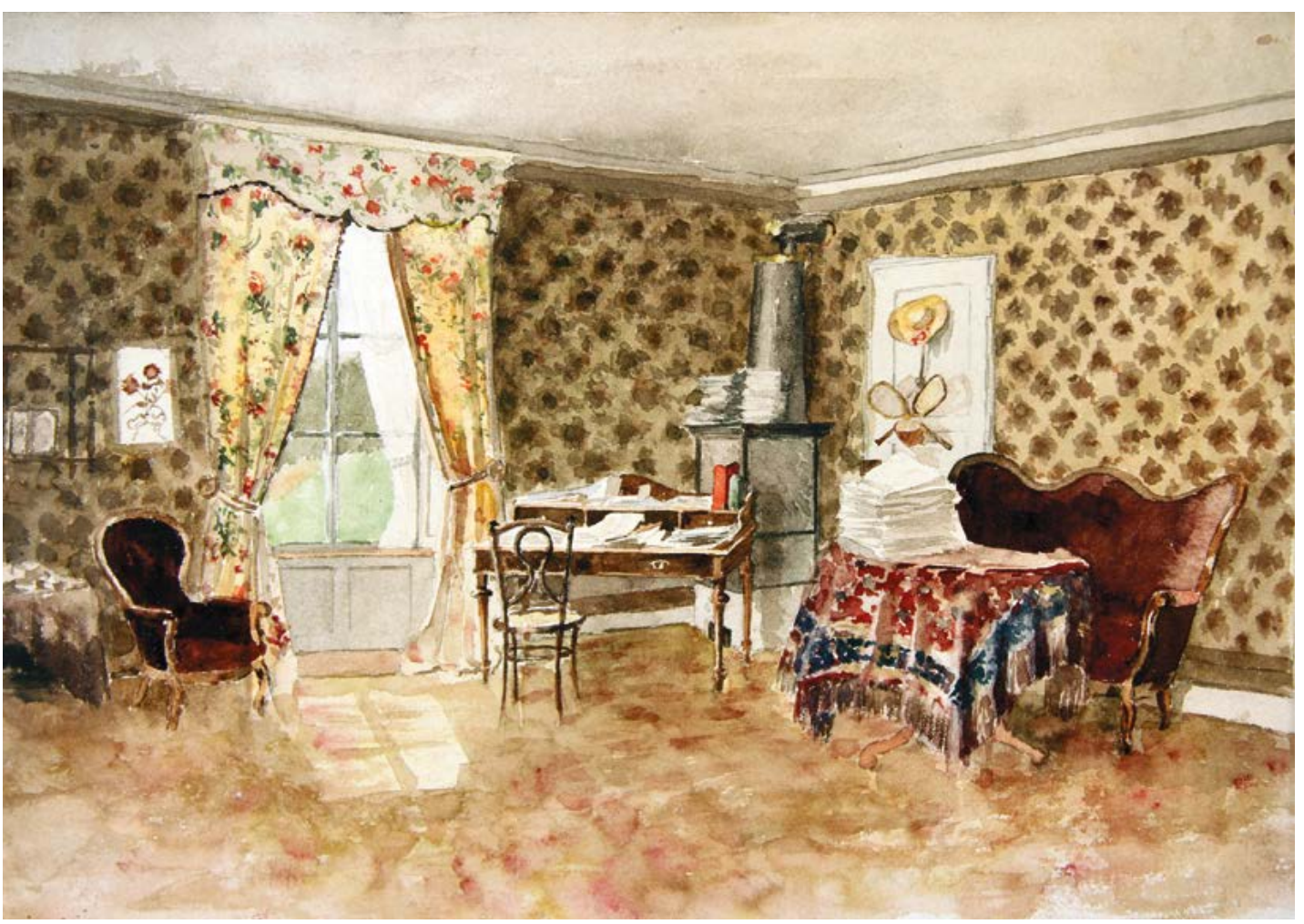

Fig. 4. Adela Crooke. Sala de estudio, h. 1885.

Las acuarelas conservadas en el IVDJ son más de un centenar en diversos formatos (desde $20 \times 25$ a $50 \times 60 \mathrm{~cm}$ ), divididas proporcionalmente en retratos, paisajes y bodegones, más un cuarto conjunto que reproduce veinte platos de cerámica y dos azulejos del museo, objetos que fueron recurrentes en el conjunto de su obra por su interés hacia este tipo de piezas.

Los paisajes son de exteriores, representando casas, vegetación, caminos, cementerios, claustros o arboledas, con excepción de un interior que representa una sala o estudio de trabajo plagado de detalles decorativos, desde el papel pintado de las paredes hasta el sombrero colgado de una puerta o los escritos sobre una mesa [fig. 4].

En los bodegones destacan las mesas revueltas formadas por telas, cerámicas, vasijas y platos, y algunas composiciones impresionistas con objetos de la vida cotidiana; también las flores y frutas, pero en este caso aisladas de otros objetos.

La característica de los retratos es su acabado final, recargado en retoques en la mayor parte de los originales, casi todos de mujeres y en planos medios. En el conjunto se aprecia la evolución formativa, desde la sencillez de los primeros paisajes de comienzos de los años ochenta hasta la colorista y densa gama de los bodegones, muchos de ellos compuestos con obras de la colección de arte de Juan Crooke.

En cuanto a los dibujos, se guardan sueltos y en ocho cuadernos de pequeño formato (10x15 $\mathrm{cm})$. Los primeros suman 76, a los que hay que añadir apuntes de piezas del Instituto adjuntos a documentos textuales (informes, cartas, resúmenes, valoraciones, etc.). Contienen retratos (38), en su mayoría femeninos, más varios estudios de cabezas; paisajes (21), entre ellos casas, puentes, marinas y arboledas; bodegones (6) de frutas, vasijas y flores, y por último animales (11): caballos, perros, pájaro y ciervo.

En los cuadernos se recogen 219 apuntes a lápiz con los que documenta la sociedad de la época a través de los tipos, paisajes y objetos representados. Destacan en el conjunto, por su número, los retratos (uno de ellos autorretrato), con diferentes planos y prioridad a los perfiles. La diversidad es la característica: personas sentadas en bancos, leyendo el periódico, paseando o 


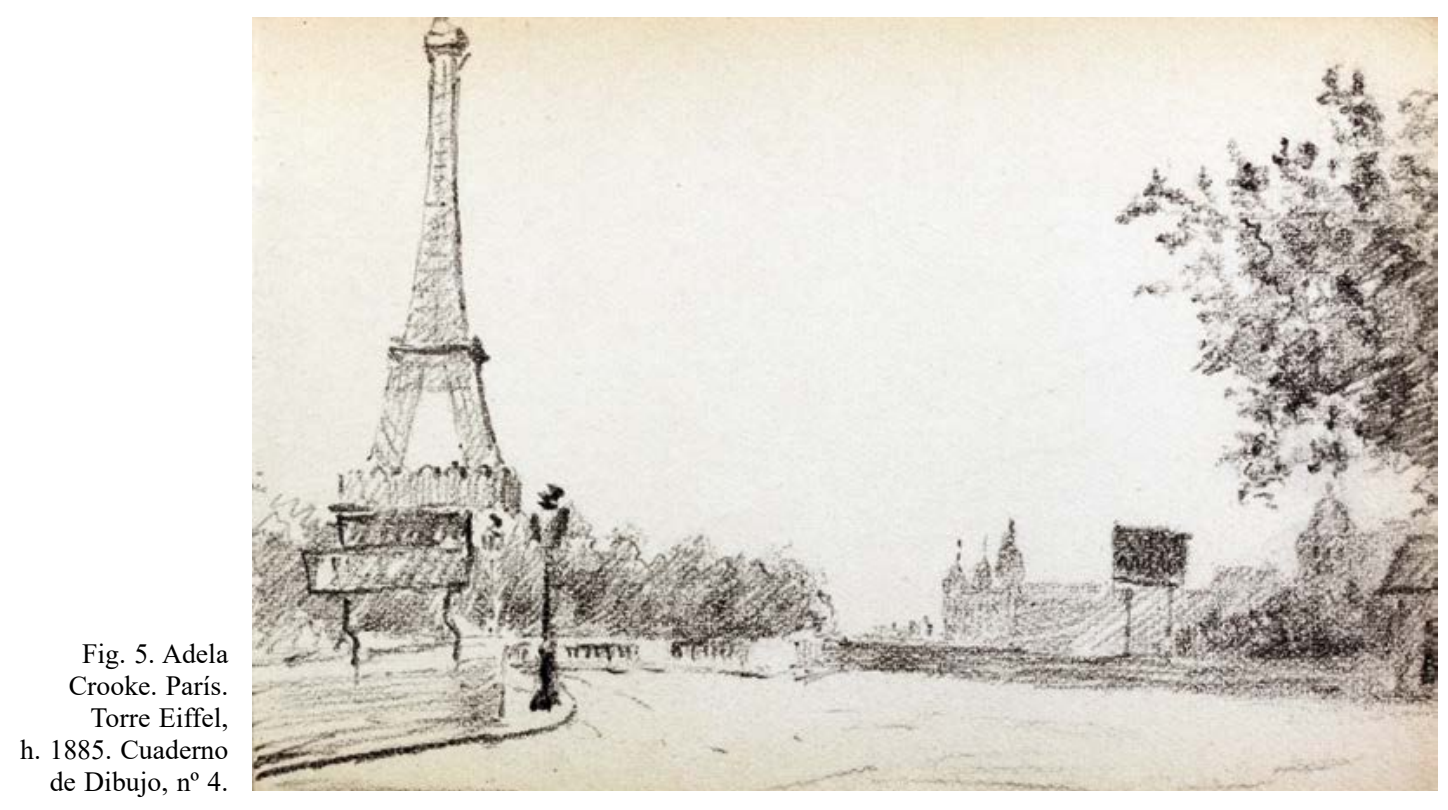

charlando; trabajadores en talleres, jardineros, conductores, carteros, niñeras con coches de bebé, soldados, curas y monjas.

Un segundo grupo lo componen los estudios, figuras y objetos: desnudos, manos, figuras escultóricas, mobiliario, libros, espadas, calderos, vasijas, jarrones, flores y floreros, hojas, árboles, caballos, burros, vacas, perros, carros, coches de caballos, automóviles, grúas, vagones de tren, bocinas, farolas, uniformes, zapatos y numerosos sombreros. Por último, en menor cantidad, pero de igual calidad, los paisajes urbanos y rurales: bosques, jardines, veleros, calles, iglesias, cafés, restaurantes y plazas. En ocasiones los apuntes y esbozos ganan en riqueza de detalles, como la vista de la torre Eiffel en el ambiente parisino [fig. 5].

\section{Obra fotográfica}

Adela Crooke practicó la fotografía con pasión y dejó un considerable legado cuya recuperación y estudio nos permite afirmar que se trata de una obra diversa en su aspecto documental, rica en contenidos, y estéticamente muy interesante. Se compone de 4.000 unidades entre retratos, paisajes y reportajes (3.200 positivos y 800 negativos), imágenes con una doble lectura: estética y documental. Para su realización empleó varias cámaras, entre ellas una para placas de gran formato $(24 \times 30$ $\mathrm{cm}$ ), y construyó un laboratorio de madera en el torreón del palacete de la calle Fortuny para revelar y positivar las imágenes [fig. 6]. Tuvo siempre un interés por coleccionar y tomar fotografías, y más que una afición fue un medio de expresión que cultivó en todas sus facetas.

Dominó el retrato, con influencia evidente del pictorialismo como se observa en las composiciones de la serie de Gran Duff con la condesa de Oberndorf, o en las de Lena Bacon Post leyendo en una estancia. En todos ellos busca el encuadre ideal para reflejar la personalidad de los personajes, y rompe la norma al realizar las tomas ligeramente contrapicadas para estilizar y realzar las figuras.

En las vistas la característica es la originalidad, con paradigma en las tomas impresionistas de Venecia, Tánger y París. Algunas de las composiciones que realizó en las calles, entre ellas las tomas de tipos en Venecia, se identifican con las que realizó Atget en el parque de Luxemburgo en París $(1898)^{37}$. En los monumentos y rincones de Ávila, Salamanca, Toledo, Guisando (Ávila) o

\footnotetext{
37 Alarcó, 2019: 174
} 


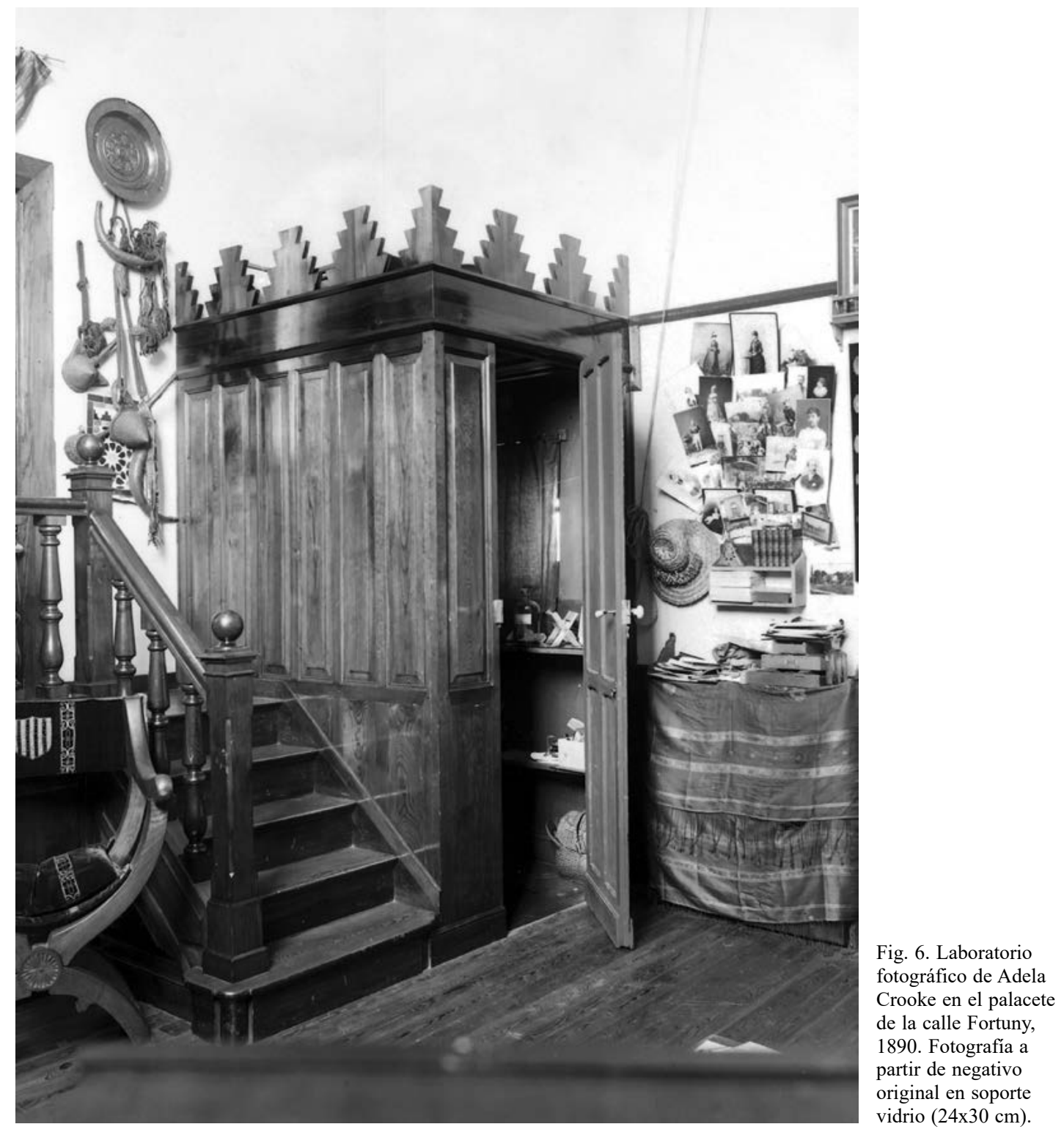

Valencia de Don Juan (León). Algunas de las fotos que realizó en las calles de París son similares a las de Charles Marville: amplias, despejadas, elegantes, tocadas por la melancolía ${ }^{38}$.

Muchos de sus paisajes tienen la influencia pictorialista de las creaciones de Constant Puyo y Robert Demachy ${ }^{39}$, caracterizados por naturalezas donde aparecen mujeres con sombrilla ${ }^{40}$. Esta corriente fue también modelo, con atención a los tipos y a escenas teatralizadas, lo que se observa también en la serie de retratos de grupo que realizó en las veladas de aristócratas y bur-

38 Véase el ejemplo en París, boulevard Haussmann, 1877 (Alarcó, 2019, p. 170).

39 Constant Puyo (1857-1933) y Robert Demachy (1859-1936) son dos de los principales representantes del pictorialismo, corriente surgida a finales del siglo XIX y que se caracterizó por proporcionar a las obras fotográficas una presentación similar a la pintura. Demachy fue uno de los fundadores del Photo Club de París en 1888, sociedad a la que también perteneció Puyo. Sus trabajos fueron referencia para una generación de autores.

${ }^{40}$ García Felguera, 2007. 
gueses, especialmente en el palacio de Liria de los duques de Alba, con quienes mantuvo gran amistad.

Los reportajes son numerosos y diversos, relacionados con asuntos oficiales como la Jura de Constitución en las Cortes por Alfonso XIII en 1902 o la boda real en 1906. El ocio tiene espacio específico en el corpus fotográfico a través de las fotos de caballos, cacerías y toros, temas que aparecen en el imaginario de la condesa con profusión de imágenes, y en un espacio único, por singular, en el caso de la mujer fotógrafa sin identificar a la que realizó una magnífica serie en los jardines de un palacio ${ }^{41}$.

Entre todos los reportajes es excepcional el viaje por el Mediterráneo en la primavera de 1897 en el yate Thistle junto a la duquesa de Alba y a la emperatriz Eugenia de Montijo ${ }^{42}$. El viaje, descrito por la duquesa en el diario titulado 3170 Millas en el Thistle ${ }^{43}$, y también por Crooke en un dietario personal, duró tres meses (12 de abril a 17 de julio), y visitaron varias ciudades de Francia, Italia, Grecia y Turquía, de las que realizó tres centenares de fotos que instaló en un álbum junto a las albúminas que adquirió en establecimientos comerciales.

Una parte de las fotografías (positivos y negativos) se conserva suelta, pero el grueso fue recopilado en los álbumes personales denominados Los viajes de Adelín, serie compuesta por seis volúmenes que reúnen las imágenes tomadas entre 1888 y 1897 por Europa, Oriente Medio y África. En el periodo indicado recorrió diez países y cincuenta y ocho ciudades en compañía de su esposo, Guillermo de Osma, y de su círculo de amistades. Suman un total de 979 albúminas en diversos tamaños.

En Los viajes de Adelín escenifica toda suerte de temas y acontecimientos que muestran las costumbres, aficiones, divertimentos y estilo de vida de la clase burguesa, espacio estructurado a partir de un deseo documental de los modos de ser y de relacionarse en un contexto determinado. Vistas de ciudades, paisajes, excursiones, monumentos, vida cotidiana, tipos populares, ocio y deportes, espectáculos, retratos, reproducciones, familia y sociedad constituyen las categorías más significativas.

\section{Pintura y fotografía o viceversa}

La relación entre pintura y fotografía en la obra de Adela Crooke parte de la práctica de la segunda bajo la óptica de la primera, y por tanto de una visión artística que tiene dos aspectos diferenciados: por una parte, la influencia de su formación pictórica en la toma de contenidos y en los encuadres, y por otra el uso de las fotografías para componer sus dibujos y acuarelas. Es decir, que conjuga las dos versiones a las que ya nos hemos referido: creación (estética) y documentación (ética).

Esta hipótesis la confirmamos desde el análisis comparativo de varias obras que han sido recuperadas del fondo documental y artístico del IVDJ: retratos y paisajes que dejaron huella en el personaje y que justifican la difusión de su universo creativo.

\section{Retrato ecuestre de Guillermo de Osma y torreón de la Casa de los Guzmanes en Ávila}

Guillermo de Osma posó para el fotógrafo parisino Ch. Barenne ${ }^{44}$ ante un decorado montado a propósito para la ocasión. La toma, impecable de factura, tanto por la pose del jinete como por la del caballo, así como por el encuadre, es un ejemplo de los trabajos que llevaron a cabo los

\footnotetext{
${ }_{41}$ Mujer fotografiando en Knowle, julio de 1909. IVDJ, Caja 10/1682-C10/1731.

42 "Tras la muerte de Napoleón III, su afición viajera no se desmintió nunca, navegando muchas temporadas en su yate Thistle. En uno de estos viajes inicia su libro el marqués de Villa Urrutia con el capítulo preliminar que titula $L a$ emperatriz Eugenia en Constantinopla en 1897" (Barras de Aragón, 1951: 215).

${ }^{43}$ IVDJ. Manuscritos 26-V.22.

44 El estudio de Ch. Barenne \& Cie se encontraba en el número 127 de la rue St. Honoré de París.
} 


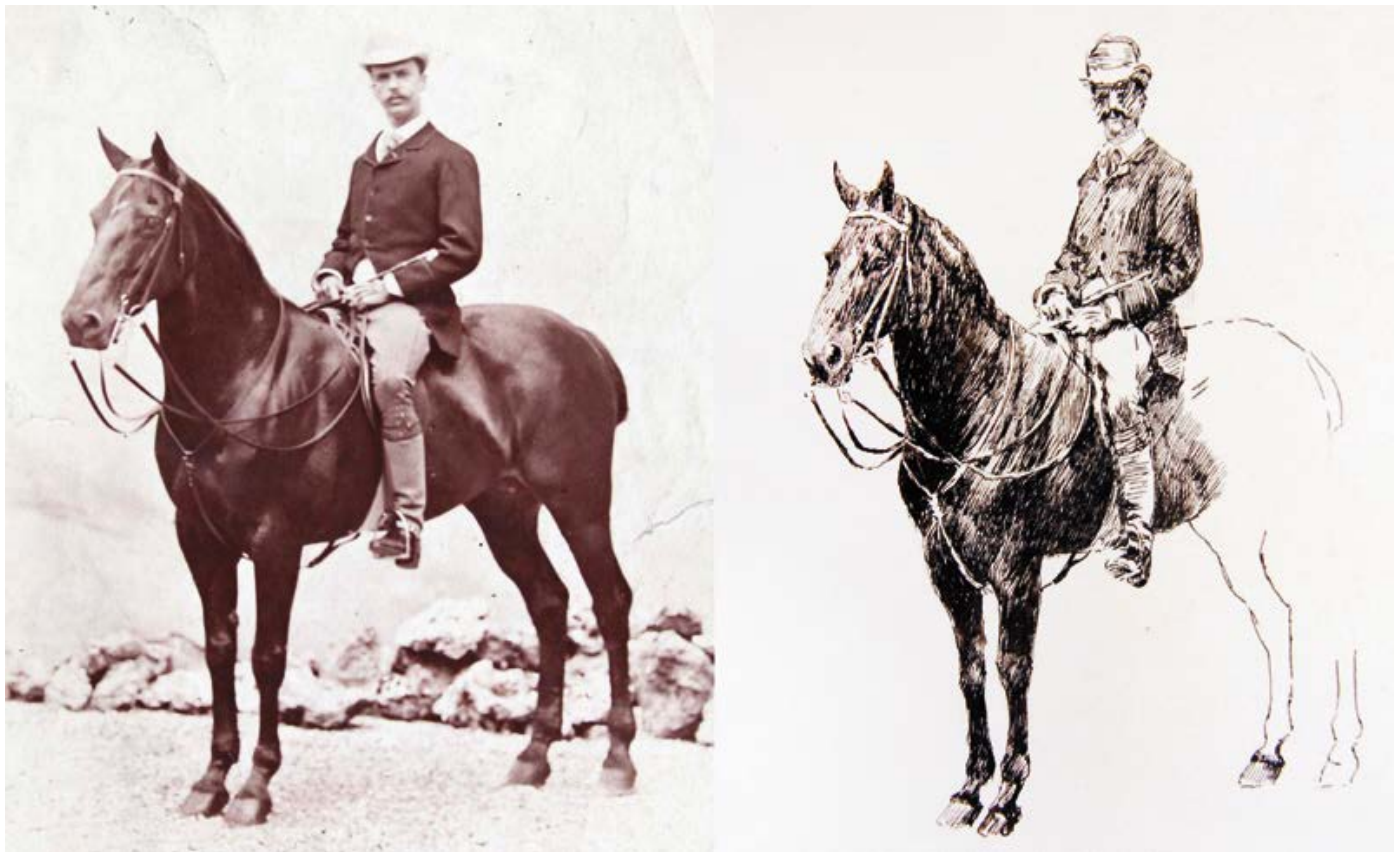

Fig. 7. Dibujo de Adela Crooke a partir del retrato ecuestre a la albúmina realizado en París por Ch. Barenne, h. 1890.

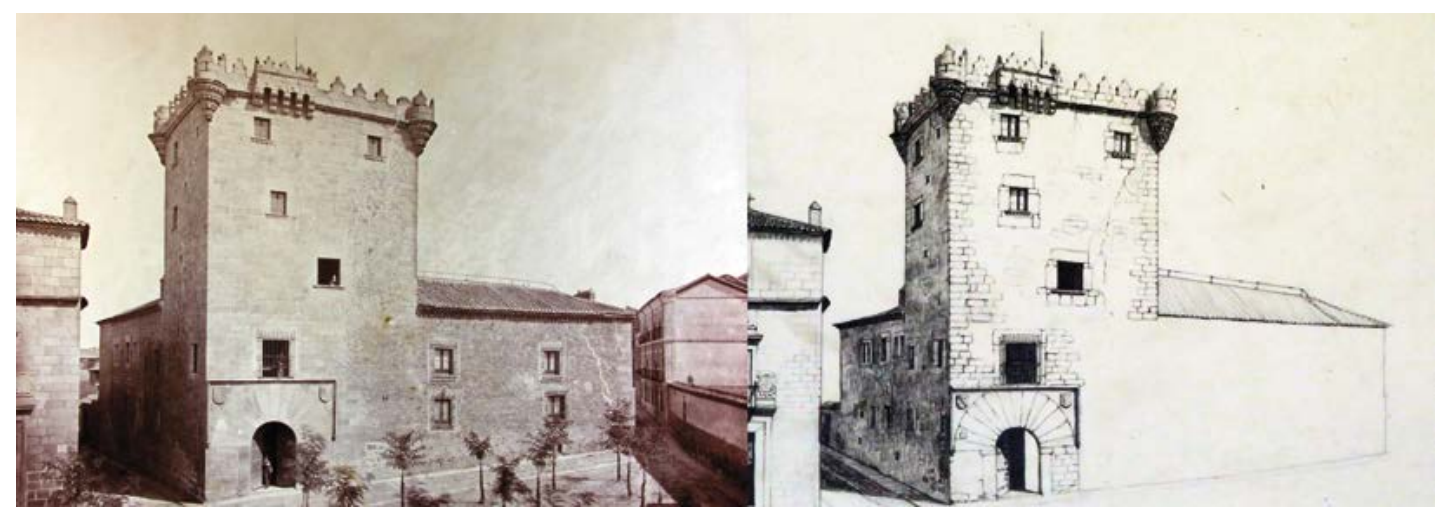

Fig. 8. Casa y torreón de los Guzmanes en Ávila. Fotografía de Laurent y dibujo de Adela Crooke, h. 1880.

retratistas franceses en ese periodo, cuyo resultado se aprecia también en el excelente positivado final. La elegante postura de Osma, erguido sobre la montura y con las manos en las riendas, conforma una estampa de gran belleza, ideal para un estudio pictórico [fig. 7].

Adela Crooke tomo la fotografía de Barenne como modelo para un ejercicio sobre el caballo (cabeza y patas delanteras), como indica el hecho de que dejara inacabada una parte del mismo (la más sencilla), y que tan solo esbozara la figura de su marido, perfectamente reconocible. La superposición de ambas imágenes revela el calco del original para obtener el perfil, obviando los detalles complementarios, tales como las piedras del fondo.

El boceto del torreón de los Guzmanes de Ávila lo realizó a partir de una excelente fotografía de Laurent ${ }^{45}$, dibujo a lápiz en el que ejercitó los trazos en línea y que también dejó inacaba-

45 Jean Laurent Minier (Garchizy, Francia, 1816-Madrid, 1886) fue el más importante fotógrafo con actividad en España en la segunda mitad del siglo XIX. Su producción de vistas de España y de reproducciones de obras de arte y 
do [fig. 8]. Seleccionó la parte central (el torreón) y la fachada izquierda del edificio para encajarlos en el entorno como elementos principales de la escena. Como en el caso anterior (retrato de Osma), se recrea en los detalles de una parte del dibujo, insistiendo en los matices de los aspectos que le interesa.

\section{Venecia impresionista}

La mirada fotográfica de Crooke sobre la ciudad de Venecia es ante todo impresionista. En el año 1888, durante el viaje de novios con Guillermo de Osma, con tan solo 25 años y sin apenas experiencia en materia de fotografía, realizó una completa serie de vistas con todo tipo de detalles, destacable además por la composición: rincones costumbristas, canales, iglesias, la plaza de San Marcos, góndolas y gondoleros, palacetes medievales, monumentos, etc.

En el álbum dedicado a ese viaje ${ }^{46}$ se conservan los originales que seleccionó como modelo para realizar uno de los dibujos más atractivos e interesantes, tanto por el contenido como por la disposición de las escenas y la presentación final en una sola estampa de cinco temas diferentes: un gondolero remando hacia un puente, vista general de la isla de San Giorgio, los arcos y balcones de un edificio señorial, y dos detalles de la plaza de San Marcos: una puerta de la catedral con palomas en el suelo y el remate de la columna con el emblemático león, símbolo de la ciudad [fig. 9].

El alarde impresionista de Crooke consistió en conjugar en una sola imagen aquellos aspectos que más llamaron su atención, partiendo de las fotografías que ella misma y su marido habían tomado, coincidiendo así en la valoración de la imagen fotográfica con los maestros del impresionismo, que se adelantaron en el tiempo a Robert de la Sizeranne, quien en 1897 todavía se preguntaba por la cuestión artística de la fotografía ${ }^{47}$.

La idea de Crooke al montar cinco dibujos en una sola imagen, si bien sin perder la identidad de cada uno de ellos, la contemplamos como antecedente de las tarjetas postales ilustradas y su función ilustrativa y/o de memoria [fig. 10]. Esta observación la vinculamos a un aspecto al que ya hemos hecho referencia anteriormente: el coleccionismo de albúminas de los lugares que visitó, adquiridas en los establecimientos comerciales y de los que también dejó muestra en sus álbumes personales.

Con esa imagen define su condición de fotógrafa amateur, que junto al resto de obras enmarcamos en la corriente pictorialista de la que fueron precursores los citados Puyo y Demachy. El resto de fotografías captadas durante ese mismo viaje y en los que realizaría posteriormente responden a una estética similar, y constituyen un conjunto documental que justifica nuestras valoraciones.

Volviendo al impresionismo, siete años después de que Crooke paseara por el laberinto de la ciudad de las máscaras, Eugène Boudin pintó en 1895 una vista de la desembocadura del Gran $\mathrm{Canal}^{48}$. Por entonces, ella ya había realizado los dibujos inspirados en la serie fotográfica que reafirman nuestra hipótesis en el uso de la foto como documento para la creación pictórica.

\section{Tánger en sepia y color}

Las fotos de los paisajes urbanos y de las tomas costumbristas del Tánger que Adela Crooke visitó con su marido durante uno de sus primeros viajes (1889), aparecen con profusión en el

\footnotetext{
objetos fue ingente. Patentó un sistema de coloreado y un nuevo tipo de papel, y editó catálogos para la comercialización de sus fondos, que catalogó con criterios propios. Sus negativos se conservan en el Instituto del Patrimonio Cultural.

${ }^{46}$ Número 6 de la serie "Los viajes de Adelín" (1888): Fotografías de Biarritz, Lucerna, Villa de Este, Milán, Venecia y Viena.

47 Robert de la Sizeranne: “Le photographie est-elle un art?", en Revue des Deux Mondes, 1897, pp. 565-595.

48 Eugéne Boudin. Vista de Venecia, 1895. Óleo sobre lienzo, $51 \times 73 \mathrm{~cm}$. Colección de Ann y Gordon Getty, San Francisco.
} 


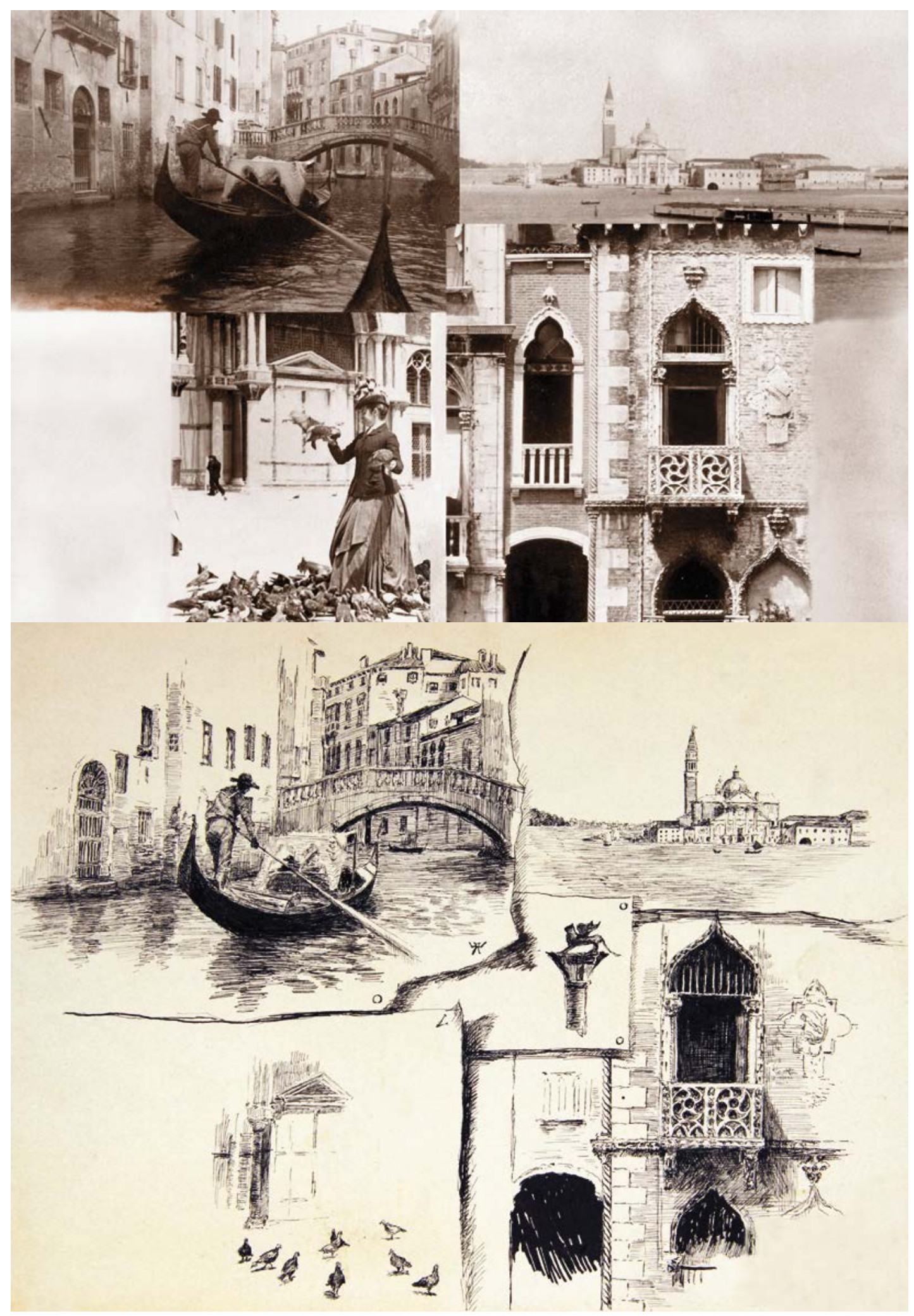

Figs. 9 y10. Dibujos de Adela Crooke a partir de las fotografías tomadas en Venecia por ella y por Guillermo de Osma durante el viaje realizado en 1888. Se observa que ha omitido su imagen.

Archivo Español de Arte, vol. XCIII, n. ${ }^{\circ}$ 372, pp. 391-408, octubre-diciembre 2020 ISSN: 0004-0428, eISSN: 1988-8511, https://doi.org/10.3989/aearte.2020.26 


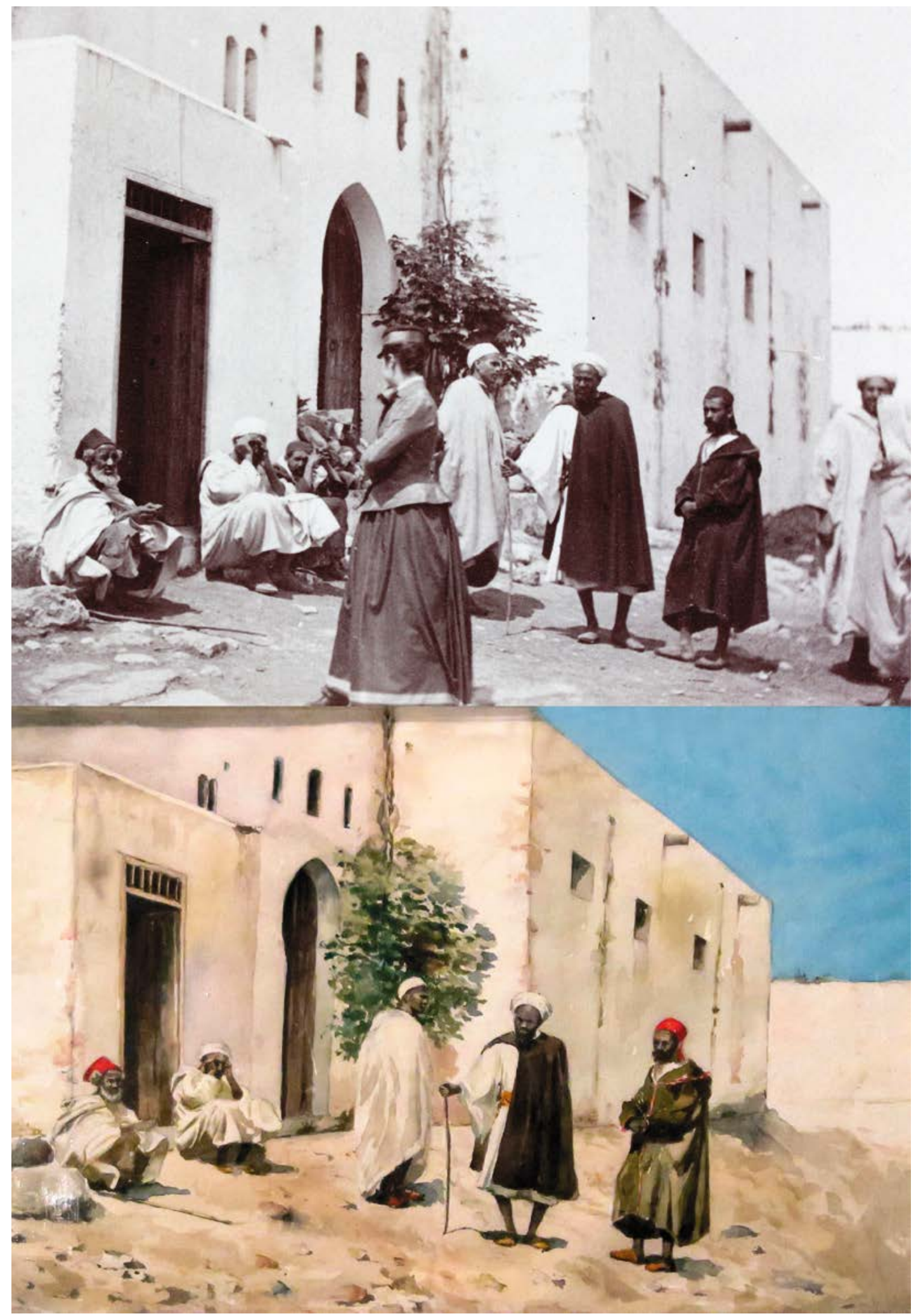

Fig. 11. Adela Crooke retratada en Tánger por Guillermo de Osma, 1889. En la parte inferior la acuarela que realizó a partir del original fotográfico, de la que eliminó su figura y redujo los personajes a cinco. 
álbum personal que diseñó al efecto. Una de esas imágenes, captada en un rincón de la ciudad, fue la elegida para pintar una escena de la vida cotidiana. En el original, obra de Guillermo de Osma, Crooke se mezcla con los tipos populares, a los que mira con interés. Su presencia en el centro de la escena palía el recelo de los tipos y facilita la toma de la imagen, probablemente pensada así de antemano.

La acuarela resulta una copia viva y lucida por los colores, respetando todos los detalles de la fotografía a excepción de la figura de la propia Adela y la de los personajes fuera de plano que no distorsionan la idea final. Técnicamente, se observa el dominio de la perspectiva y las proporciones, aunque la foto sea más estilizada. En la comparación de las dos obras se advierte la fidelidad al origen, salvo en aspectos mínimos como el arco de la puerta o el retoque de la vegetación [fig. 11].

\section{Coloreado de fotografias}

Es este un aspecto interesante, ya que las placas para la obtención de fotos en color (autocromos) no se comercializaron hasta 1907 por los hermanos Lumiére. Los estudios previos no habían dado resultados positivos y el coloreado se efectuaba por retocadores o pintores, función que desarrollaron, entre otros artistas, Joaquín Sorolla en la galería del valenciano Antonio García, o Isidro Gamonal en la de Kaulak.

Adela Crooke practicó el coloreado sobre albúminas, con un ejemplo paradigmático en un retrato propio. Este tipo de trabajos podemos relacionarlo con el que Édouart Manet realizó sobre las reproducciones a la albúmina de sus propios cuadros, encargadas al fotógrafo Anatole Go$\operatorname{det}^{49}$, a partir de las que preparó planchas para grabados ${ }^{50}$, técnica que fue recurrente para muchos de los impresionistas

Partiendo de la albúmina original (sin firma ni logotipo en el cartón, y probablemente tomada hacia 1885), Crooke realizó dos interpretaciones a la acuarela y al óleo; el primero sencillo y con una selección clara de las zonas a destacar, el segundo recargado y con interpretación de los elementos [fig. 12]. En la acuarela, los tonos son suaves, con dominante verde (sillón, vestido y fondo), consiguiendo un efecto delicado, pero irreal y al mismo tiempo falto de contraste. Como resultado, se observa un cambio en el gesto del personaje debido al rojo intenso de las mejillas y al retoque en los ojos, con pérdida de detalles en el peinado y en los bordados del vestido.

En la segunda interpretación, óleo sobre papel fotográfico, modifica los colores hacia tonos rojos (vestido y sillón), con azules de fondo para dibujar la figura. El resultado en este caso es más cercano a la albúmina, y al mismo tiempo más impactante en detrimento de la elegancia de la acuarela. En suma, la fotografía es transferida al lenguaje de la pintura, pero con la riqueza de matices que la autora quiere añadir. Como revelan los ejemplos analizados, la fotografía no solo es utilizada como apunte, sino también como la posibilidad de crear pictóricamente una imagen única, una obra personal.

\section{Conclusiones}

Las creaciones de Adela Crooke Guzmán la definen como una intelectual comprometida con su tiempo, por el interés en el coleccionismo y en el estudio del arte, actividades que la llevaron a fundar, junto a su marido Guillermo de Osma, el Instituto de Valencia de Don Juan, considerado uno de los museos más importantes de España en artes decorativas.

\footnotetext{
49 Anatole Louis Godet (París, 1839-Neuilly-sur Name, 1887), amigo personal de Manet, era especialista en reproducción de obras de arte. Su obra fotográfica se conserva en la Morgan Library de Nueva York, Fundación Custodia de París, el Museo Francés de la Fotografía en Bièvres, y Paul Getty Museum (Los Ángeles).

${ }^{50}$ Alarcó, 2019, pp. 253-267.
} 


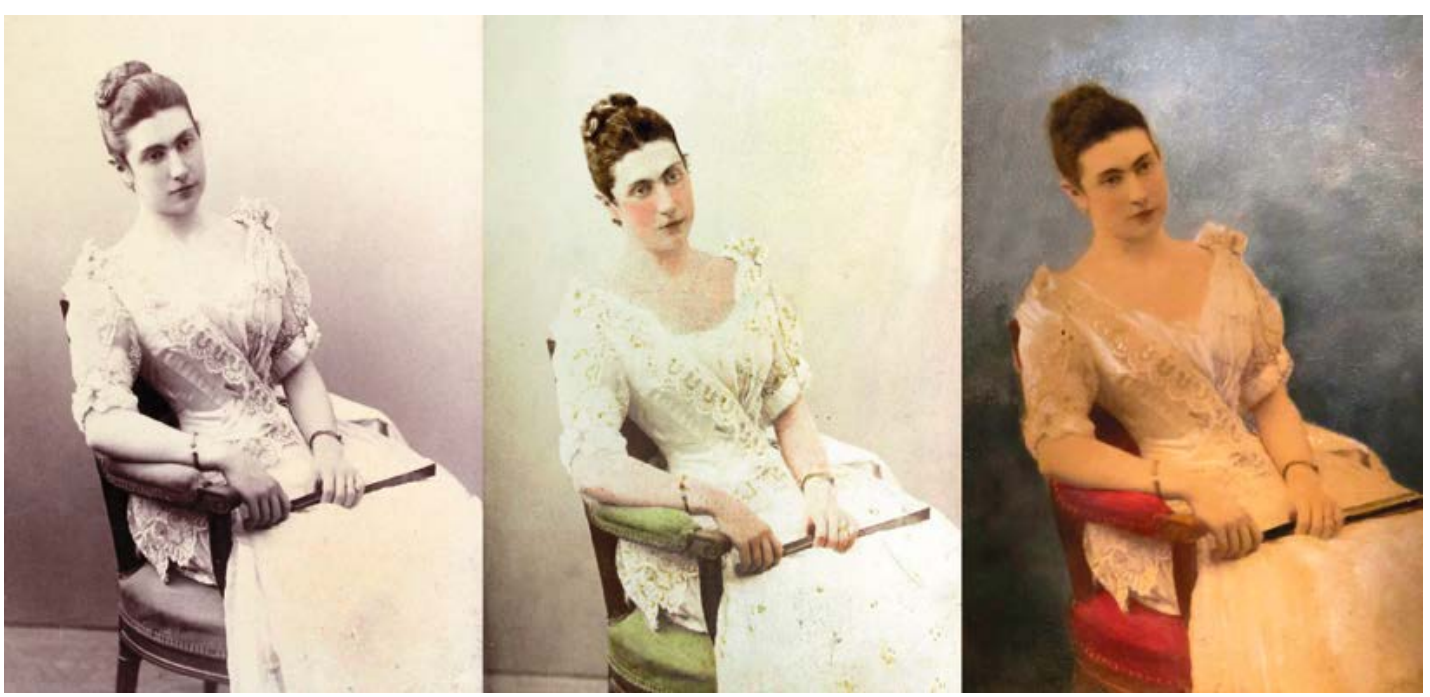

Fig. 12. Retrato a la albúmina de Adela Crooke coloreado con acuarela y óleo, h. 1885-1890.

De la investigación se concluye en primer lugar que Adela Crooke ocupa un lugar de relevancia entre las artistas amateurs de su época, con formación especializada en el taller de Alfredo Perea en lo que se refiere al dibujo y la acuarela, y autodidacta en cuanto a la fotografía, como lo prueban el laboratorio instalado en el Instituto y la documentación donde aparece practicando el arte de Daguerre (toma de imágenes, negativos, pruebas positivas y álbumes personales).

La cantidad de originales, cerca de cinco mil piezas conservadas en el Instituto de Valencia de Don Juan entre acuarelas, dibujos y fotografías, confirman la necesidad de su estudio y difusión, de forma que el inventario y la clasificación del conjunto contribuyan a la contextualización sociocultural y a conocer la aportación a la fotografía y arte pictórico de la burguesía española y de los círculos amateurs.

Por consiguiente, desde una perspectiva general, se contribuye a la difusión de nuevos datos sobre el papel de la mujer en el marco cultural decimonónico. Desde la particular, se añade un nombre propio a la relación de intelectuales que contribuyeron al desarrollo artístico y científico de país, y que durante más de un siglo ha permanecido invisible. Queda demostrado mediante las obras analizadas (originales inéditos) que Adela Crooke es un ejemplo del uso de la fotografía por la burguesía en España, y del empleo de la misma para sus creaciones pictóricas.

$\mathrm{Su}$ obra pictórica y fotográfica se enmarca cronológicamente a finales del siglo XIX, dentro del impresionismo y pictorialismo. En este sentido, el análisis de la misma nos permite afirmar que sus características coinciden con las de ambas corrientes, consideración que se reafirma con el uso reiterado de la fotografía como documento para la creación de la obra pictórica. Este trabajo es una aportación en esta línea historiográfica, proporcionando nuevas referencias sobre las afinidades e influencias mutuas entre fotografía y pintura. Los ejemplos de contraposición de imágenes que aquí se analizan demuestran claramente la relación entre estos dos lenguajes de las artes plásticas.

Por último, la información que aquí se presenta aporta nuevos datos para la historia de la pintura y la fotografía españolas. Así mismo, se abren nuevas vías de investigación en estos campos y en aquellos otros que se derivan de los contenidos de las obras: geografía, viajes, urbanismo, arquitectura, antropología, monumentos, aspectos sociales, moda, etc.

\section{BIBLIOGRAFÍA}

Alarcó, Paloma (2019): Los impresionistas y la fotografia. Madrid: Museo Thyssen-Bornemisza.

Barras de Aragón, Francisco (1951): "Mujeres viajeras". En: Boletín de la Real Sociedad Geográfica, Anuario.

Brunet, François (2000): La naissance de l'idée de photographie. París: PUF. 
Carabias Álvaro, Mónica (2000): Lady Clementina Hawarden (1822-1865): Madrid: Orto.

Carabias Álvaro, Mónica (2002a): "Coleccionismo y posesión de la imagen femenina en la fotografía de Lewis Carroll". En: Luchas de género en la historia a través de la imagen. Málaga: Diputación, pp. 519-538.

Carabias Álvaro, Mónica (2002b): Tratado fotográfico sobre el retrato femenino. Antonio Cánovas “Kaulak” o el arte de la belleza. Madrid: Ayuntamiento de Madrid.

Carabias Álvaro, Mónica (2013): "Alicia, entre la realidad y la ficción. Fotografías de Lewis Carroll y Victoria Sorochinski”. En: Arte y Sociedad, 4, pp.1-20.

Cherry, Deborah (2000): Beyond the frame: feminism and visual culture. London, New York: Routledge.

Fernández Bremon, José (1882): "Exposición del Círculo de Bellas Artes". La Ilustraciòn Española y Americana, 30 de marzo, p. 27.

Freund, Giséle (1936), La photographie en France au dix-neuvième siècle: essai de sociologie et d'esthétique. Paris: Monnier.

Freund, Giséle (1976): La fotografía como documento social. Madrid: Gustavo Gili.

García Felguera, María de los Santos (2007): “Arte y fotografía I. El siglo XIX”. En: Sougez, Marie Loup (Coord.): Historia general de la fotografia. Madrid: Cátedra, pp. 215-261.

García Ramos, Francisco José / Felten, Uta A. (Ed., 2019): Fotografía [Femenino plural] Visiones, ensayos y otros escritos sobre mujeres fotógrafas. Madrid: Fragua.

Jacobi, Carol / Kingsley, Hope (2016): Painting with Light. Art and Photography from the Pre-Raphaelite to the Modern Age. London: Tate.

Jiménez Ochoa de Alda, Maite (2010): La Fotógrafa Eulalia Abaitua (1853-1943): Bilbao: BBK.

Lázaro Martínez, Ángeles (2002): Inventario de álbumes fotográficos. Madrid: Instituto Valencia de Don Juan.

Lázaro Martínez, Ángeles (2003): Guía-inventario de retratos fotográficos. Madrid: Instituto Valencia de Don Juan.

Lemagny, Jean Claude (1992): L'Ombre et le Temps. Essais sur la photographie comme art. Paris: Nathan, 1992.

Nebreda Martín, Lara (2018): La colección de arte y arqueología andalusí del Instituto de Valencia de Don Juan. Análisis y estudio documental, Madrid, Real Academia Matritense de Heráldica y Genealogía.

Nebreda Martín, Lara (2019): "Biografía de una condesa”. En: Adela Crooke. Pasión por la fotografia. Madrid: Fragua, pp. 21-58.

Nochlin, Linda / Bolloch, Joelle / Allen, Esther (1997): Women in the 19 th Century: Categories and Contradictions. Paris: Museo d'Orsay.

Onfray, Stephany (2018): "Ellas: de modelo a fotógrafa. La mujer como impulsora de nuevas formas retratísticas en los estudios fotográficos madrileños (1860-1880)". En: Área abierta. Revista de comunicación audiovisual y publicitaria, 18 (1), pp. 13-38.

Partearroyo Lacaba, Cristina (2010): “Crooke y Guzmán, Adelaida”. En: Diccionario Biográfico Español. Madrid: Real Academia de la Historia, t. XV. p. 207.

Partearroyo Lacaba, Cristina (2013): "El Instituto Valencia de Don Juan: Don Guillermo de Osma y la condesa de Valencia de Don Juan”. En: Casas museo: museología y gestión: Actas de los congresos sobre casas museo (2006, 2007, 2008): Madrid: Ministerio de Educación, Cultura y Deporte, pp. 44-59.

Ribemont, Francis / Daum, Patrick / Prodger, Phillip (2006): Impressionist Camera: Pictorial Photography in Europe, 1888-1918. London, New York: Merrell.

Roger, Christiane (1991): El pictorialisme francés, 1896-1930. Colleccions de la Societé Française de la Photographie. Barcelona: Sa Nostra.

Rouillé, André (1982): L'empire de la photographie: photographie et pouvoir bourgeois, 1839-1870, Paris: Le Sycomore.

Rouillé, André (2017): La fotografía. Entre documento y arte contemporáneo. México: Herder.

Salvador Benítez, Antonia (2009): "Mujeres tras la cámara. Fotógrafas en la Andalucía del siglo XIX". En: Homenaje a la profesora Isabel Torres. Estudios de Documentación dedicados a su memoria. Granada: Universidad de Granada, pp. 807-822.

Sánchez Vigil, Juan Miguel; Editor (2019): Adela Crooke. Pasión por la fotografía. Madrid: Fragua.

Sánchez Vigil, Juan Miguel / Olivera Zaldua, María (2014): “Fondos fotográficos del Instituto de Valencia de Don Juan. Los negativos de Adela Crooke". En: Documentación de las Ciencias de la Información, vol. 37, pp. 163-203.

Santos Quer, María Ángeles (2009, 2004): Guía-inventario de la colección fotográfica del Instituto Valencia de Don Juan. Madrid: Biblioteca del Instituto Valencia de Don Juan.

Scharf, Aaron (1994): Arte y fotografia. Madrid: Alianza.

Sougez, Marie Loup (1997): "La mujer en la fotografía española". En: La mujer en el arte español. Actas VIII Jornadas de Arte, 26-29 nov. Dpto. de $\mathrm{H}^{\mathrm{a}}$ del Arte Diego Velázquez. Madrid: Centro de Estudios Históricos del CSIC, pp. 549-558.

Zelich, Cristina (1998): La fotografía pictorialista en España. Barcelona: Fundación La Caixa.

Fecha de recepción: 13-I-2020

Fecha de aceptación: 23-VI-2020

Archivo Español de Arte, vol. XCIII, n. ${ }^{\circ}$ 372, pp. 391-408, octubre-diciembre 2020

ISSN: 0004-0428, eISSN: 1988-8511, https://doi.org/10.3989/aearte.2020.26 